\title{
Reconstruction of the Pre-Trial Decision on the Delegation and the Main Trial Process in Indonesia Based on Justice Value
}

\author{
H. Sunarso ${ }^{1 *}$, Mahmutarom ${ }^{2}$, Akhmad Khisni ${ }^{3}$, Muhammad Ngazis ${ }^{3}$ \\ ${ }^{1}$ Doctorate Student of Faculty of Law Sultan Agung Islamic University Semarang, Indonesia \\ ${ }^{2}$ Faculty of Law Wahid Hasyim University Semarang, Indonesia \\ ${ }^{3}$ Faculty of Law Sultan Agung Islamic University Semarang, Indonesia
}

\begin{abstract}
DOI: $10.36348 /$ sijlcj.2020.v03i12.005
| Received: 26.11.2020 | Accepted: 08.12.2020 | Published: 13.12.2020
\end{abstract}

*Corresponding author: H. Sunarso

\section{Abstract}

This research aim is to examine and analyze pre-trial implementation of delegation and trial of main cases based on Law Number 8 of 1981 concerning Criminal Procedure Law in Indonesia currently and How to reconstruct the policy formulation of the pre-trial decision on the delegation and trial of the main case in an effort to maximize the pre-trial function in the criminal justice system in Indonesia in accordance with the value of justice? this research uses the method of empirical juridical approach where The data used in this study are primary data and secondary data, using qualitative analysis. The results showed that the Problems that arise in the pre-trial implementation of the delegation and trial of the main case based on Law Number 8 of 1981 cannot be applied because in Article 156 paragraph (1) the Court is not authorized to hear the case, or the indictment cannot be accepted, or the indictment must be annulled, or pre-trial has been granted regarding legal or Whether or not arrest, detention, termination of investigation or prosecution, compensation and or rehabilitation for a person whose criminal case is terminated at the level of investigation or prosecution, and whether or not the determination of a suspect is valid therefore, The reconstruction of the policy formulation of the decision of the Pre-Trial against the delegation and trial of the main case is by adding a sentence (phrase) so that in order to uphold justice and legal certainty the judge has a legal basis or reason for accepting objections or the exception of the accused or his legal adviser.

Keywords: Reconstruction, Pre-Trial, Justice Value.

Copyright $\odot$ 2020 The Author(s): This is an open-access article distributed under the terms of the Creative Commons Attribution 4.0 International License (CC BY-NC 4.0) which permits unrestricted use, distribution, and reproduction in any medium for non-commercial use provided the original author and source are credited.

\section{INTRODUCTION}

In handling a criminal case, the issue of pretrial detention becomes a crucial problem in the practice of criminal procedure law in Indonesia. The absolute power of investigators to detain someone suspected of committing a criminal act with the threat of a certain punishment makes detention so easy. As a result, detention houses were filled with prisoners, both detention centers managed by the Directorate General of Corrections under the Ministry of Law and Human Rights (Kemenkumham), as well as detention centers managed by the police. Almost all detention centers in Indonesia are overcrowded, which has a negative impact on the conditions of detainees. In addition, the limited supervision of the judiciary through the PreTrial mechanism of the investigating institution made arbitrary acts against detainees in the form of torture, both physical and psychological, during the investigation process. This situation is partly influenced by the ease with which conditions for detention are made in the Criminal Procedure Code as seen in Article
21 Paragraph (4) of the Indonesian Penal Procedure Codes (KUHAP) which states that:

"A suspect or defendant may be subjected to detention in a criminal act if: (a) the threat of imprisonment for five years or more; (b) against the perpetrator of a criminal offense whose penalty is less than five years."

In the Constitutional Court (MK) decision regarding the judicial review of the Criminal Procedure Code, the Constitutional Court stated that pre-trial was a new breakthrough in the Indonesian criminal justice system. The Constitutional Court explained that the Revised Native Regulations/ Herziene Inlandsche Reglement (HIR) which adheres to the inquisitory system, does not recognize this institution. In the inquiry system, a suspect or defendant is placed under examination as an object that may experience arbitrary treatment by the investigator of the suspect. Thus, since the first examination before the investigator, the suspect 
has been deemed guilty. Meanwhile, the Criminal Procedure Code has placed suspects/ defendants no longer as objects of examination, but as human subjects who have equal dignity, dignity, and position before the law. Pre-trial is intended as a control mechanism against the possibility of arbitrary actions by investigators or public prosecutors in carrying out arrests, searches, seizures, investigations, prosecutions, terminations of investigations, and termination of prosecution, whether accompanied by requests for compensation and/or rehabilitation or not.

In practice, the use of Pre-Trial mechanisms is often not optimal, which can be seen from the minimal use of this mechanism in criminal proceedings. In fact, Pre-Trial is the right of all suspects/defendants when their civil liberties are deprived. The minimal use of Pre-Trial mechanisms can be seen from a number of factors. Luhut M. P Pangaribuan [1] argues that, although this concept is an adoption of the habeas corpus, judges in pre-trial tend to be ineffective in supervising investigators or public prosecutors, especially in the use of force.

In Pre-Trial case examinations, courts often do not examine the requirements in accordance with the Criminal Procedure Code in carrying out arrests, detention, or other coercive measures. But just checking administrative procedures, such as completeness of letters. This means that if all the administrative requirements have been fulfilled, then the forceful attempt is considered valid by the court.

In practice, the Court itself acknowledges that there are many obstacles in the Pre-Trial. In addition to the incompleteness of the rules, "necessity", which is only administrative in nature, the court is also required to maintain good relations with investigators and prosecutors as a consideration [2]. When a court grants a Pre-Trial request, often there is an unhappy relationship between the court and the investigator, but on the one hand, the court must also uphold justice.

Along with the times, the determination of a suspect has become one of the objects of Pre-Trial or as a preliminary legal action for the suspect or his family, examining pre-trial applications using ordinary criminal procedural law, we often see the phenomenon of pretrial applications filed by suspects to cancel or test whether against the determination of the suspect as legal or not.

If the pre-trial request is granted, the investigator can terminate the investigation (SP3), if the pre-trial application for the determination of the suspect is rejected, the legal process will continue to the court, but there is also the determination of the suspect to have been canceled by the court, and the subject matter is still delegated to the court for then it is tried by the court, and in the first trial the accused or his legal adviser has submitted an objection or exception to the indictment letter from the public prosecutor.

This problem is what urges the author to study it further in a research with the following issues:

1. What are the problems that arise in the pre-trial implementation of delegation and trial of main cases based on Law Number 8 of 1981 concerning Criminal Procedure Law in Indonesia currently?

2. How to reconstruct the policy formulation of the pretrial decision on the delegation and trial of the main case in an effort to maximize the pre-trial function in the criminal justice system in Indonesia in accordance with the value of justice?

\section{METHOD OF RESEARCH}

The paradigm that is used in the research this is the paradigm of constructivism which is the antithesis of the understanding that lay observation and objectivity in finding a reality or science knowledge [3]. Paradigm also looked at the science of social as an analysis of systematic against Socially Meaningful Action through observation directly and in detail to the problem analyzed.

The research type used in writing this paper is a qualitative research. Writing aims to provide a description of a society or a certain group of people or a description of a symptom or between two or more symptoms.

Approach method used in this research is Empirical-Juridical [4], which is based on the norms of law and the theory of the existing legal enforceability of a law viewpoint as interpretation.

As for the source of research used in this study are:

1. Primary Data, is data obtained from information and information from respondents directly obtained through interviews and literature studies.

2. Secondary Data, is an indirect source that is able to provide additional and reinforcement of research data. Sources of secondary data in the form of: Primary Legal Material and Secondary Legal Materials and Tertiary Legal Material.

In this study, the author use data collection techniques, namely literature study, interviews and documentation where the researcher is a key instrument that is the researcher himself who plans, collects, and interprets the data [5]. Qualitative data analysis is the process of searching for, and systematically compiling data obtained from interviews, field notes and documentation by organizing data into categories, describing it into units, synthesizing, compiling into patterns, selecting important names and what will be studied and make conclusions. 
RESEARCH RESULT AND DISCUSSION Problems That Arise in the Pre-Trial Implementation of Delegation and Trial Of Main Cases Based On Law Number 8 Of 1981 Concerning Criminal Procedure Law In Indonesia Currently

Based on the results of research conducted at the Central Jakarta District Court, in the period from 2016 to 2019, the Central Jakarta District Court has examined and tried a number of pre-trial case in determining whether an arrest, detention, investigation, termination of prosecution, and determination of a suspect was legal or not.

Furthermore, in 2017, there were 12 pre-trial petitions regarding the legality of an arrest, detention was legal, termination of investigation or prosecution, and whether the determination of the suspect is legal or not. In 2018 a number of 24 Pre-Trial requests regarding whether an arrest is legal or not, whether or not detention is legal, whether an arrest, detention, investigation, termination of prosecution and determination of a suspect was legal or not and in 2019 there were pre-trial requests with a total of 20 Pre-Trial requests regarding whether or not an arrest, detention, investigation, termination of prosecution, and determination of a suspect was legal or not.

Based on the aforementioned data, from year to year, Pre-Trial applications have increased, namely requests regarding whether an arrest, detention, investigation, termination of prosecution, and determination of a suspect was legal or not.

This is, as the authors explain in this research, regarding Pre-Trial petition regarding whether an arrest, detention, investigation, termination of prosecution, and determination of a suspect was legal or not, as regulated Article 77 of the Criminal Procedure Code (KUHAP) as stated in Article 82 paragraph (3) letter (a) states in accordance with the provisions stipulated in this Law concerning whether or not an arrest, detention, investigation, termination of prosecution, and determination of a suspect was legal or not has been stated in the Constitutional Court Decision of the Constitutional Court Number 21 / PUU / XII / 2014.

Based on the description above, it can be concluded that in practice the implementation of the Criminal Procedure Code (KUHAP) is currently faced with new problems (the determination of the suspect by the investigator has been cancelled by the court and is considered illegitimate according to law but the main trial of the case continues) which then it cannot be resolved by the Procedural Law itself or it can be said that there is a legal vacuum, and the legal vacuum is clearly injurious to justice seekers in the context of protecting human rights.

Pre-trial is one of the new things in the law enforcement system in Indonesia which aims to uphold and protect the human rights of suspects at the level of investigation and prosecution. If "pre-trial" is interpreted literally, it can be interpreted as pre, which means before or before trial. Means "pre-trial" is the same as an examination before the court.

The pre-trial institution is an imitation or can be equated with a commissioner judge institution (rechter commissioner) in the Netherlands and a judge of $d$ 'instruction in France, but pre-trial in Indonesia has a difference, namely that its authority is not as broad as commissioner judges in Europe. According to Oemar Soeno Adji [6], the rechter commissaris agency or judge leading the preliminary examination appeared as a manifestation of the judge's activeness. Judges in Central Europe have important positions having the authority to handle coercion (dwang middelen), detention, seizure, body searches, housing and examination of documents. Judge of d 'instructions in France have broad powers in preliminary examinations. According to Andi Hamzah [7]: "Likewise the Judge of $\mathrm{d}$ 'Instruction in France, has broad powers in preliminary examinations. He examined the accused, witnesses and other evidence. He can make reports, searches of homes and certain places. After the preliminary examination has been completed, he determines whether a case is sufficient reason to be submitted to court or not. "

If we examine the term used by the Criminal Procedure Code "Pre-Trial", then the meaning and meaning are literally different. Pra means before, or precedes, means "Pre-Trial" is the same as before examination in a court session (before examining the subject matter of the Public Prosecutor's indictment). In Europe such an institution is known, but its function is to actually carry out preliminary examinations. So the function of the Judge Commissioner (Rechter commissioner) in the Netherlands and Judge of $d$ 'Instruction in France can really be called Pre-Trial, because in addition to determining whether an arrest, detention, seizure is legal or not, it also carries out a preliminary examination of a case. For example, the public prosecutor in the Netherlands can ask a judge's opinion on a case, whether, for example, the case deserves to be sidelined by a transaction (for example, if the case is not brought to trial by compensating the victim and the perpetrator of the criminal act) or not.

Even though there are similarities with the commissioner judge, the Pre-Trial authority is limited. The authority to decide whether an arrest or detention is legal or not. Is the termination of an investigation or prosecution legal or not. It did not say whether the confiscation was legal or not.

According to Oemar Seno Adji [8], the rechter commissioner (judge leading the preliminary examination) emerged as a manifestation of the activeness of judges, who in Central Europe have an 
important position which has the authority to handle coercive measures (dwangmiddelen), detention, confiscation, searches of bodies, houses and examinations the letters.

According to the Indonesian Criminal Procedure Code, Pre-Trial does not have that broad authority. The commissioner judge, apart from, for example, has the authority to judge the legality of an arrest, detention like Pre-Trial, as well as whether or not a confiscation carried out by the prosecutor is legal. In addition, if the Commissioner Judge in the Netherlands supervises the implementation of the prosecutor's duties, then the prosecutor does the same on the implementation of police duties, the Pre-Trial in Indonesia shall supervise the two agencies. Likewise, judge of $d$ 'instruction in France has broad powers in preliminary examinations. He examined the accused, witnesses, and other evidence. He can make minutes, search houses and certain places, carry out arrests, confiscate, and close certain places. After the preliminary examination has been completed, he determines whether a case has sufficient reason to be submitted to the court or not. If there is enough reason, he will send the case by means of a delivery letter called the Ordinance de Renvoi, on the other hand, if there is no sufficient reason, he will release the suspect using the Ordinance de non lieu.

Reconstruction of The Policy Formulation Of The Pre-Trial Decision On The Delegation And Trial Of The Main Case In An Effort To Maximize The PreTrial Function In The Criminal Justice System In Indonesia In Accordance With The Value Of Justice Pre-trial is one of the preliminary legal processes that can be used by the suspect[9], suspect's family, or a third party to claim their rights which have been regulated in the provisions of the law in the legal process since the investigation, investigation, determination of the suspect, whether the procedure has been carried out by the apparatus law enforcers have complied with the provisions of the legislation in force or not.

In the Criminal Procedure Code, the Pre-Trial petition is regulated in Law No. 8 of 1981 concerning Criminal Procedure Law (KUHAP) Article 1 point 10 reads "Pre-trial is the authority of the district court to examine and decide according to the method regulated in this law, concerning:

1. Whether or not an arrest and/or detention is legal at the request of the suspect or his family or the other party at the power of the suspect;

2. Whether or not the termination of investigation or prosecution at the request is legal for the sake of upholding law and justice;

3. A request for compensation or rehabilitation by the suspect or his family or the other party on his behalf whose case has not been filed in court.
In addition to these provisions, Article 77 of the Criminal Procedure Code reads "The District Court is authorized to examine and decide, in accordance with the provisions stipulated in this Law concerning:

a) Whether or not an arrest, detention, termination of the investigation, or prosecution is legal.

b) Compensation and/or rehabilitation for a person whose criminal case is terminated at the level of investigation or prosecution.

c) Whether the determination of a suspect is legal by the investigator. (Constitutional Court Decision Number: 21 / PUU-XII / 2014, dated April 28, 2015).

In this research, the author argues that the problem that the Pre-Trial on the determination of the suspect has been granted by the court, but the case is still delegated by the public prosecutor to the court to hear the main case.

Regarding the aforementioned problems in the main case trial, as stipulated in Article 156 paragraph (1) of the Criminal Procedure Code, the defendant through his legal advisor has submitted an exception or objection. The content of Article 156 paragraph (1) of the Criminal Procedure Code is as follows "In the event that a defendant or legal adviser submits an objection that the court is not authorized to hear his case or the indictment cannot be accepted or the indictment letter must be canceled, after being given the opportunity for the public prosecutor to express his opinion, the judge to consider the objection and then make a decision ".

Whereas in case Number 34 / Pid.Sus-TPK / 2018 / PN.JKT PST on behalf of Edward Seky Soeryadjaya, there was a legal vacuum, in this case, the defendant's legal adviser had submitted an objection or an exception regarding whether the Pre-Trial request No. 40 / Pid.Pra / 2018 / PN.Jkt.Sel, April 23, 2018, on behalf of the Defendant, Edward Seky Soeryadjaya [10], while in the Pre-Trial case has canceled:

a) Determination of the Suspects (PIDSUS/18) Number: TAP/51/F.2/ Fd.1 / 10/2017, dated 26 October 2017 is invalid and groundless and has no binding power;

b) Investigation Order for the Director of Investigation at the Junior Attorney General for Special Crimes Number: PRINT-93 / F: /Fd.1/10/2017, dated 27 October 2017 is illegal and has no legal basis and has no binding force;

c) Decision of South Jakarta District Court Pre-trial Number 40 / Pid.Pra / 2018 / pN.Jkt.Sel, April 23, 2018, which has obtained permanent legal force;

Then, the Public Prosecutor in response to the objection/exception, which in essence is that the Public Prosecutor rejects the exception on the grounds that the defendant's exception is rejected because, in principle, the Defendant's exception has deviated from the provisions of Article 156 (1) of the Criminal Procedure 
Code, where none of the material the objection which is the reason for the objection referred to in Article 156 (1) of KUHAP;

Whereas the Pre-Trial has been regulated as in Article 77 of the Criminal Procedure Code and the Constitutional Court Decision Number 21 / PUU-X11 / 2014, dated 28 October 2014, that is basically if the Main Case has begun to be examined while the PreTrial filing has not been decided, then the Pre-Trial petition will be annulled. But not the other way around, the Pre-Trial has been decided and granted, but the subject matter of the case has not yet been examined, does not mean that the subject matter of the case is null and void;

Whereas then the Panel of Judges has given its considerations which in essence the Pre-Trial have been regulated as in Article 77 of the Criminal Procedure Code and the Constitutional Court Decision Number 21/PUU-XI/2014, October 28, 2014, that is basically if the Main Case has begun to be examined while the PreTrial filing has not decided, then the Pre-Trial petition is invalidated, but not the other way around, the PreTrial has been decided and granted, but the subject of the case has not yet been examined, does not mean that the subject matter of the case is null and void;

Apart from this, after the Assembly studied and paid attention to all laws and regulations, especially regarding the Criminal Procedure Code and the doctrines of legal experts/scientists, it turned out that there was no single statutory regulation stipulating that the Main Case Council must comply with the Pre-Trial Decision, In addition to these reasons, Article 156 paragraph (1) of the Criminal Procedure Code only regulates: the subject matter of objection/exception is regulated, namely: (1) The court is not authorized to hear the case, (2) The indictment cannot be accepted, (3) The indictment must be annulled so that based on the legal reasons the defendant's exception was not accepted and the trial of the main examination of the case was continued.

Based on the foregoing, the judge did not dare to accept the exception/objection of the defendant's legal adviser, on the one hand, the basis of a person being brought to trial because he was suspected of committing a criminal act because he was suspected of being a criminal offender was then named a suspect, while the suspect's status had been canceled by the judiciary through the Pre-Trial process. However, the judge did not dare to accept these perceptions/objections, this is because there are no rules or laws governing exceptions that must be granted if the suspect's determination has been canceled through PreTrial.

Based on the description above, the Reconstruction of the rules for the decision of the Pre-
Trial against the delegation and the main trial of the case is to add to the sound of Article 156 paragraph (1) The court is not authorized to try the case, (2) or the indictment cannot be accepted, (3) or the indictment must be is canceled, (4) or Pre-trial has been granted regarding whether or not the arrest, detention, termination of investigation or prosecution has been granted, compensation and or rehabilitation for a person whose criminal case is terminated at the level of investigation or prosecution, and whether or not the determination of a suspect is valid, so based on reasons The law stated that the defendant's exception was not accepted and the trial of the main examination of the case was continued.

\section{CONCLUSION}

1. Problems that arise in the pre-trial implementation of the delegation and trial of the main case based on Law Number 8 of 1981 concerning Criminal Procedure Law in Indonesia currently can be seen at the application stage, where the judge has no reason or legal basis to accept the objection of the defendant or his legal adviser if there is an exception or objection raised by the defendant or his legal adviser regarding whether or not a PreTrial has been granted or not the arrest, detention, termination of investigation or termination of prosecution, compensation and or rehabilitation for a person whose criminal case is terminated at the level of investigation or prosecution, and whether the determination of a suspect is legal or not, it cannot be applied because in Article 156 paragraph (1) the Court is not authorized to hear the case, or the indictment cannot be accepted, or the indictment must be annulled, or pre-trial has been granted regarding legal or Whether or not arrest, detention, termination of investigation or prosecution, compensation and or rehabilitation for a person whose criminal case is terminated at the level of investigation or prosecution, and whether or not the determination of a suspect is valid.

2. The reconstruction of the policy formulation of the decision of the Pre-Trial against the delegation and trial of the main case is by adding a sentence (phrase) so that The court does not have the authority to try the case, or the indictment cannot be accepted, or the indictment letter must be canceled, or pre-trial has been granted regarding whether or not the arrest is legal, detention, termination of investigation or termination of prosecution, compensation and or rehabilitation for a person whose criminal case is terminated at the level of investigation or prosecution, and whether or not the determination of a suspect is valid, so that in order to uphold justice and legal certainty the judge has a legal basis or reason for accepting objections. or the exception of the accused or his legal adviser. 


\section{REFERENCES}

1. Luhut, M. P. P. (2008). Hukum Acara Pidana: Surat-surat Resmi di pengadilan oleh Advokat: Praperadilan, Eksepsi, Duplik, Memori Banding, Kasasi, Peninjauan Kembali, Cet.V, Djambatan, Jakarta, 39.

2. Tornado, A. (2018). Praperadilan Sebagai Upaya Penegakan Prinsip Keadilan. Al-Adl: Jurnal Hukum. 10:237. 10.31602/al-adl.v10i2.1366.

3. Faisal. (2010). Menerobos Positivisme Hukum, Rangkang Education, Yogyakarta.

4. Johnny, I. (2005). Teori dan Metodologi Penelitian Hukum Normatif, Bayumedia, Surabaya.
5. Moleong, L. (2002). Metode Penelitian Kualitatif, PT Remaja Rosdakarya, Bandung.

6. Oemar, S. A. (1980). Hukum Pidana, Erlangga, Jakarta, 88.

7. Andi, H. (2016). Hukum Acara Pidana Indonesia Edisi Kedua, Cet. XI, Sinar Grafika, Jakarta, 188.

8. Op.cit

9. Purba, T. (2018). Praperadilan Sebagai Upaya Hukum Bagi Tersangka. Papua Law Journal. 1:253-270. 10.31957/plj.v1i2.591.

10. Suharjo. (2020). Perluasan Kewenangan Praperadilan Dalam Menentukan Tersangka Pelaku Tindak Pidana. Reformasi Hukum. 23:132148. 10.46257/jrh.v23i2.92. 